Research Reports / Rapports de recherche 



\title{
Performing Our Stories, Performing Ourselves: In Search of Kenya's Uhuru Generation
}

\author{
Mshai S Mwangola*
}

"Each generation must, out of relative obscurity, discover its mission, fulfil it or betray it”. Frantz Fanon, 206.

\section{Introduction}

'Performing Our Stories, Performing Ourselves: In Search of Kenya’s Uhuru Generation' is an auto-ethnographical study of the first generational cohort of Kenya's post-colonial era. ${ }^{1}$ It explores the concept and reality of an 'Uhuru Generation' in Kenya by exploring the lives and creative responses of three of its articulators in the contexts in which they exist. The dissertation is a conversation between story-tellers, whose artistic careers and intellectual work approach the idea of a generational historical mission through the re-creation, invocation and facilitation of performance as a site of individual and communal reflection. In this way, the dissertation exemplifies Orature as an aesthetic intellectual tradition focussing on the transcending of boundaries in the making of meaning.

This study uses as its point of departure the vibrant debate that greeted Njonjo Mue’s July 2000 seminal identification of Kenya’s ‘Uhuru Generation’ as:

that generation of women and men born after the midnight hour of December 12, 1963... [T] [he true daughters and sons of Kenya, having been born after the country joined the family of sovereign nations, in contrast to those naturalised citizens born before this date who had to give up the citizenship of the empire when Kenya was born in $1963 .^{2}$

That debate became critical in bringing interventions into the Kenyan public sphere that one might characterise as the youth discourses defining the emergence of a new national generational cohort. ${ }^{3}$ The existence, definition, potential and agenda of an Uhuru Generation are still very much a

* Depatment of Performance Studies, Northwestern University, Evanston, IL, USA.Email:mfwamwangola@gmail.com,s-mwangola@northwestern.edu. 
subject of discussion in Kenya, more than a decade after the idea first emerged in the small discussion groups whose deliberations inspired Mue's address. Despite the widespread acceptability of the term, especially in the political realm, there are still multiple perspectives as to what exactly it entails, who should be included in its definition, and whether it serves any useful purpose as a signifier of socio-political commitment, vision or agenda.

Guiding this investigation into some of the theoretical and practical possibilities embedded within this concept is an understanding of performance as a site for the enactment of multiple, sometimes simultaneous, discourses. As 'a means by which people reflect on their current conditions, define and/or reinvent themselves and their social world, and either reinforce, resist, or subvert prevailing social orders' (Drewal 2), performance becomes a way of knowing the generational cohort that the three artists at the centre of this research identify with. Using the lens offered by their commitment to the art of storytelling, and their own journeys discovering and using the process of storytelling and its products, I have crafted a multi-faceted narrative of what it means to belong to the Uhuru Generation.

\section{The Uhuru Generation}

Uhuru Generation discourse rests on two founding principles. First is the ideal associated with the transition from colony to republic articulated as 'Uhuru'. Second is the contemporary manifestation of an endogenous sociopolitical tradition coalescing around indigenous principles of generational organisation.

The word 'Uhuru' as employed here, may be traced back to the beginning of the new socio-political dispensation that began with the end of the colonial era in Kenya. The achievements of the attainment of self-government (madaraka) in June 1963 and of 'flag independence' (uhuru wa bendera) in December later that year, followed by the transition to a republic (jamhuri) in December 1964, were later widely acknowledged to have fallen short of the dreams long cherished by those who had fought for a fully independent Kenyan nation. Just a few years after these national milestones, the republic's first vice-president, Oginga Odinga, one of the negotiators and signatories to the Independence Constitution, defined the reality that followed as 'not yet Uhuru'. He argued, 'Freedom is not just raising a flag. Freedom is not just having political power. Freedom, national freedom, requires economic independence and cultural independence' (Oruka and Odinga 50).

This distinction between 'uhuru wa bendera', the legal but limited status of independence from the direct rule of a colonial master symbolised by national symbols such as a flag, and 'Uhuru' as articulated above by Odinga is crucial. As Amilcar Cabral points out, 'the chief goal of the liberation 
movement goes beyond the achievement of political independence to the superior level of the complete liberation of the productive forces and the construction of economic, social and cultural progress of the people' (52). For the rest of the century, the battle to define how the vision articulated as 'Uhuru' ought to be realised, dominated the political scene in Kenya. Despite the different personalities and phases of this struggle, it remained essentially a conflict of political ideology, as Kenyans joined the rest of the continent in embracing Kwame Nkrumah's challenge to 'seek first the political kingdom' in the hope of seeing 'all these [other] things.... added as well'. The political battle pitted those who advocated a radical transformative approach bringing about a decisive break with the status quo prevailing at the end of the colonial era, against those who favoured a reformative, generally conservative agenda. As it turned out, the latter were able to win and keep control of the state for the first four decades of Kenyan independence; thus the phrase 'not yet Uhuru' became indelibly associated in the first couple of decades of the post-colonial era with those fighting for radical transformation. By the beginning of the eighties however, the struggle took on a new dimension, and the call for Uhuru underwent a metamorphosis, becoming the push for 'true democracy' initially envisioned as liberal pluralism, which the radicals hoped would enable the attainment of their transformative agenda.

With the new millennium however, amidst growing disenchantment with multi-party politics as experienced in Kenya, a new discourse recovered Odinga's formulation, centring it in the emergence of a critique of the national status quo, which sought to consolidate a new social movement around the idea of a generational mission. Its articulators chose to rally themselves around the historical event of the national transition from colony to republic; measuring Kenya's success at achieving that promised to the post-colonial era generations as their birthright - the legacy defined as Uhuru. Pointing out the glaring discrepancy between the dream and the reality, they attributed it to the failure of their generational predecessors in overcoming the historical challenges that followed the attainment of madaraka, uhuru wa bendera, and jamhuri. At the same time, they expressed their frustration at being collectively marginalised in decision-making forums influencing or determining the state of the nation. ${ }^{4}$ Uhuru Generation discourse thus emerged out of attempts to formulate a collective mission that would enable the generational cohort born around Kenya's emergence from colonialism meet the contextual challenges of attaining the vision articulated as uhuru.

In his seminal treatise on decolonisation, The Wretched of The Earth, Frantz Fanon makes a persuasive argument for the identification of a generational mission in the fight for decolonisation. The idea of a collective mission, based on meeting the challenges of a particular historical moment, 
is also enshrined in principles of socio-political organisation found in several of the indigenous nations gathered together by British imperialism into what is today the Kenyan republic. One such prominent tradition, manifested differently in diverse cultural and historical contexts in the pre-colonial and colonial eras, was that of using generational cohorts to organise societies. Understanding tradition as the on-going transmission of the past through the present to the future, I trace in this study the evolution of the concept of generational organisation from its roots in the pre-colonial era through to its current manifestation in contemporary Kenyan society. I construct a narrative of the Kenyan nation using the stories of successive generations, identifying each with a mission derived from the challenges particular to the historical context of its existence. These ranged from the imposition of British colonial rule, to the struggle to come to terms with the drastically changed sociopolitical environment that resulted, and finally the struggle to create a truly independent republic out of a colony. I argue that the emergence of Uhuru Generation fits naturally within this plotline, and examine here a selected number of interventions intended to turn theory into practice, shaping its mandate and consolidating it as a distinct entity whose members have the full rights and responsibilities of citizenship in the project of making the nation.

\section{Presenting Our Stories, Presenting Ourselves}

The lives and work of the three people at the centre of this research project provide an opportunity to explore multiple contexts and facets of Uhuru Generation discourse, and also contribute to the crucial question of the creation of knowledge in, about, and of Africa. To this end, the dissertation both reflects and reflects on story - the crafted, creative, representation of (real or imagined) lived experience - by using it as the epistemological framework for undertaking, interpreting and reporting this research project. I engage the three storytellers as conscious actors who have chosen, each in his or her own unique way, to be active participants in the project of shaping the social movement that is the Uhuru Generation. At one and the same time, they model the "thinking men and women of words", the eloquent men and women of mobilisation and the 'practical men and women of action', that Shadrack Nasong'o identifies as crucial to the successful emergence and consolidation of a social movement (21). The investment they have individually and collectively made in defining the vision of the Uhuru Generation allows an examination of the contemporary manifestation in Kenya of the decolonisation / democratisation project.

I examine here the processes and products that have enabled Aghan Odero, Mkawasi Mcharo and Abubakar Zein to actively participate in translating the vision of the Uhuru Generation into reality. I emphasise in this study the 
existence of multiple perspectives in the central concept of an Uhuru Generation. Therefore each case study is considered within an exploration of the contextual realities that have influenced the direction that one of these artists has taken in conceptualising and contributing to the development of an agenda that he or she sees as fundamental to enabling this generational cohort to successfully fulfil its historical mission. Beginning with an exploration of the legacy of the academic debates accompanying the challenge of decolonising the Kenyan academy in the first couple of decades of independence, and going on to consider the evolution of present understanding and practices of democracy in the nation, the study extends beyond the physical boundaries of the Kenyan nation to engage the growing national diaspora and the challenges of living in the borderlands of citizenship. While each approach is distinctly unique, corresponding as it does to the priorities identified by the artist under consideration, they collectively form part of the collective body of thought and action contributing to the imagining and consolidating into being of this generational cohort. They model the importance of performance as a way of knowing; affirming Margaret Drewal's articulation of artistic performance as the primary site of knowledge production, consumption and transmission on the African continent.

\section{Notes}

1. 'Post-colonial era' as used here refers to the period following the end of the colonial era and is not an indicator of the success at achieving Uhuru.

2. Mue makes no indication of the cut-off point at the other end. I argue in the dissertation that the Uhuru Generation is only the first of Kenya's postcolonial era generations.

3. I have discussed generational youth discourses in Kenya elsewhere. See 'Leaders of Tomorrow?'

4. Kenyans born after 1963 form a majority of the population. However, they are marginalised in political, economic and socio-cultural decision-making forums where they are dismissed as youth, 'leaders of tomorrow' who cannot yet be trusted with the responsibilities of leadership in these crucial areas. See 'Leaders of Tomorrow' for an extensive discussion of this.

\section{References}

Cabral, A., 1973, Return to the Source: Selected Speeches, New York: Monthly Review Press.

Drewal, M. T., 1991, 'The State of Research on Performance in Africa', African Studies Review 34.3:1-64.

Fanon, F., 1963, The Wretched of the Earth, Paris: Presence Africaine. 
Liyong, Taban lo, 1991, Culture is Rutan, Nairobi: Longman Kenya.

Mue, N., 2004, 'The Uhuru Generation - The Messiah Within: Redeeming the Soul of our Generation', 1 July 2001, Africawired Perspectives, 20 October.

Mwangola, M. S., 2007, 'Leaders of Tomorrow? The Youth and Democratisation in Kenya’, eds., Godwin Murunga and Shadrack Nasong’o, Kenya: The Struggle for Democracy, London, New York: Zed Books; Dakar, Senegal: CODESRIA. 129-163.

Nasong’o, S. R., 2007, 'Negotiating New Rules of the Game: Social Movements, Civil Society and the Kenyan Transition', eds., Godwin Murunga and Shadrack Nasong’o, Kenya: The Struggle for Democracy, London, New York: Zed Books, Dakar, Senegal: CODESRIA. 9-57.

Oruka, H. O.and Odinga, A. O., 1992, Oginga Odinga: His Philosophy and Belief, Nairobi: Initiatives Publishers. 